
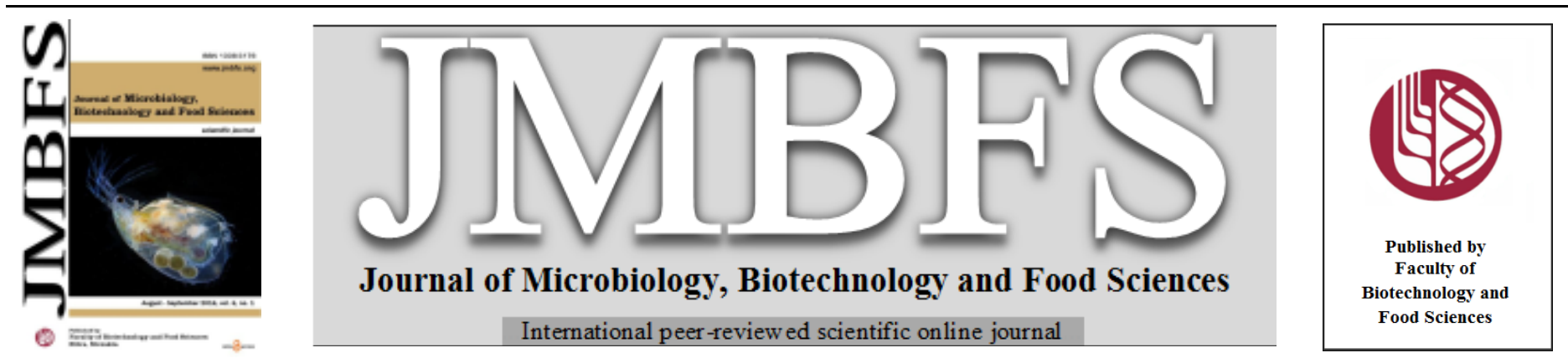

\title{
ROSEMARY, THYME AND OREGANO ESSENTIAL OILS INFLUENCE ON PHYSICOCHEMICAL PROPERTIES AND MICROBIOLOGICAL STABILITY OF MINCED MEAT
}

\author{
Sonia Amariei ${ }^{1}$, Maria Poroch-Serițan $*^{1}$, Georg Gutt ${ }^{1}$, Mircea Oroian ${ }^{1}$, Elena Ciornei ${ }^{2}$
}

Address(es):

${ }^{1}$ Stefan cel Mare University of Suceava, Faculty of Food Engineering, Department of Food Technologies, Production and Environmental Safety, Universitatii Str., no. 13, 720229, Suceava, Romania, Tel/ Fax: +40 230.520267, Tel +40 230.216147.

${ }^{2}$ Suceava County Department of Public Health, Romania, Scurta Str., no. 1A, 720223, Suceava, Romania.

*Corresponding author: mariap@ fia.usv.ro

doi: 10.15414/jmbfs.2016.6.1.670-676

\section{ARTICLE INFO}

Received 27. 8. 2015

Revised 8. 12. 2015

Accepted 4. 4. 2016

Published 1. 8. 2016

Regular article

OPEN $\partial$ ACCESS

\section{ABSTRACT}

In this paper we have analysed the capacity of essential oils from aromatic plants in order to slow or stop down the physicochemical degradation and microbiological infestation of raw minced meat processes. Three essential oils: thyme, rosemary and oregano were chosen for the experimental study due to their acknowledged antiseptic effect and their flavour acceptance by consumers. The physicochemical and microbiological properties for a mixture of pork and beef meat were analysed throughout four days. Water content, total fat, total protein, easily hydrolysable nitrogen, $\mathrm{pH}$ and water activity were determined. The experimental measurements were performed considering the following concentrations: $0.5,1.0$ and $1.5 \%$ for the essential oil incorporated into meat. The evaluation of microbiological stability was determined as well. The results indicated that essential oils have a significant influence on the physicochemical properties correlated with microbiological stability when prolonging the shelf - life of minced meat.

Keywords: Essential oils, microbiological stability, minced meat, physicochemical analysis, shelf - life

\section{INTRODUCTION}

Alteration of meat consists in a set of processes that affect the substrate, leading to formation of low molecular weight compounds in conjunction with the development of microbial associations. The consequences are the modification on sensory properties, on nutritional quality and advanced alteration conducting to a negative impact of the product on consumer's health. Different oils from aromatic plants can have preserving effect on meat. Antimicrobial effect of essential oils is acknowledged due to their hydrophobicity, being capable of damaging the cell wall of microorganisms, disturbing the metabolism of phospholipids from cytoplasmic membrane, damaging cell membrane proteins and increasing the permeability of cell wall, thus leading to loss of the liquid constituents of the cell (Burt 2004; Bakkali et al., 2008; Bassolé and Juliani 2012). The antimicrobial activity of essential oils may be related to more than one component. It is considered that the strong character of antibacterial essential oils against food borne pathogens is due to their rich content in phenolic compounds such as: carvacrol, eugenol (2-methoxy-4- (2-propenyl) phenol) and thymol (Faleiro et al., 2003; Burt 2004; Erkan et al., 2011a; Faleiro 2011; Proestos et al., 2013a). Phenolic compounds from plants contain the highest antioxidant potential, being able to decrease the local concentration of oxygen, form chelates with transition metals, inhibit the initialization of oxidative processes chain by free radicals. In addition they are capable for regenerating endogenous $\alpha$-tocopherol in lipoprotein layer from tissues (Kähkönen et al., 1999; Frankel and Meyer 2000; Rocha-Guzmán et al., 2007; Su et al., 2014) The preserving effect of oils from aromatic plants such as rosemary (Rosmarinus officinalis L.), thyme (Thymus vulgaris L.) and oregano (Origanum vulgare L.) was analysed in this paper. The synergic action of thymol and carvacrol in the essential oils of thyme and oregano inhibits the growth of several bacteria strains, e.g. Escherichia coli, Bacillus cereus, Salmonella typhimurium, Staphylococcus aureus, Listeria monocytogenes, Pseudomonas Aeruginosa (Helander et al., 1998; Burt 2004; Cox and Markham 2007; Roldán et al., 2010; Erkan et al., 2011b; Bassolé and Juliani 2012; Erkan 2012). Compounds such as carvacrol and thymol get the major antioxidant capacity from their essential oils (Kulisic et al., 2004; Erkan and Bilen 2010; Chatli and Joseph 2014). Pork and beef meat added with $3 \%$ oregano essential oil showed lower levels of oxidation after 12 days of refrigerated storage (Fasseas et al., 2008). Oregano essential oil $(0.05 \%$, $0.5 \%$ and $1 \%$ ) could delay the growth of microorganisms and decrease the final counts of spoilage microorganisms (Skandamis and Nychas 2001; Zhang et al., 2010; Zhou et al., 2010). The effect of these oil compounds on food has become much more important since their antimutagenic, anti-inflammatory anticarcinogenic, anti-haemolytic and immuno-stimulating effect was demonstrated (Barnes et al., 2005; Bakkali et al., 2008; Chao et al., 2008; Dung et al., 2009; Ocaña-Fuentes 2012; Ozkan and Erdoğan 2011; Proestos et al., 2013b; Ramchoun et al., 2015; Sá et al., 2014; Sivasothy et al., 2012; Wojdyło et al., 2007).

The purpose of our study is to evaluate the possibility of extending shelf - life of minced meat with rosemary, thyme and oregano essential oils additions, under safety conditions by maintaining nutritional value and sensory properties without bringing any chemical or microbiological threat to consumer`s health.

\section{MATERIAL AND METHODS}

Samples

The matrix chosen was purchased from a local market from Romania, consisted in a minced meat (equal mixture of beef and pork), intended to immediate consumption and stored at $4^{\circ} \mathrm{C}$. The whole amount was mixed and homogenized, and then the batch of minced meat was divided into ten portions. A portion was kept as a control sample and each of the other portions were further mixed with an appropriate volume of rosemary, thyme and oregano essential oil (final concentrations $0 ; 1$ and $1.5 \% \mathrm{v} / \mathrm{w}$ ). The samples were placed into 50 plastic containers, closed and stored at $4^{\circ} \mathrm{C}$. All physicochemical and microbiological determinations were performed at equal time intervals over a period of 4 days, in compliance with the Romanian standards.

\section{Reagents}

All the reagents used were purchased from Sigma - Aldrich and they were of pro analysis purity: 2, 2'-diphenyl-1picrylhydrazyl (DPPH), ethanol, L(+)-ascorbic acid, Folin-Ciocalteu reagent, sodium carbonate, gallic acid, quarter-strength Ringer's solution, peptone, meat extract, yeast extract, $\mathrm{D}(+)$ glucose, dipotassium hydrogen phosphat, sodium acetate trihydrate, triamonium citrate, magnesium sulphate heptahydrate, manganous sulphate tetrahydrate, malt extract, peptone, maltose, dextrin, glycerol, monopotassium phosphate, ammonium chloride, petroleum ether, $\mathrm{H}_{2} \mathrm{SO}_{4}, \mathrm{NaOH}$, Tashiro indicator, $\mathrm{MgO}$ and paraffin oil. 


\section{Oils Analysis}

Ten grams of rosemary, thyme and oregano essential oils were sterilized at $121^{\circ} \mathrm{C}$ for $15 \mathrm{~min}$ (Autoclave Raypa). The spectrophotometric assay was used for the analysis of the following properties of essential oils: antioxidant activity with 2 , 2'-diphenyl-1picrylhydrazyl (DPPH) radical scavenging considering the method described by Brand-Williams et al. (1995) (UV VIS - NIR Spectrometer Shimadzu, 3600, Japan) and total polyphenol content with Folin-Ciocalteu method (spectrophotometer Shimadzu UV-2550, Japan) by Fujita et al. (2012).

\section{Microbiological Analysis}

Samples $(10 \mathrm{~g})$ of minced meat were aseptically weighed, added to sterile quarterstrength Ringer's solution $(90 \mathrm{ml})$ and homogenized in a stomacher (Lab Blender - BagMixer 400 P, INTERSCIENCE, France) for $60 \mathrm{~s}$ at room temperature. Decimal dilutions in quarter-strength Ringer's solution were prepared and duplicate $1 \mathrm{ml}$ samples of appropriate dilutions were poured or spread on the following media made from basic ingredients considering the method described by Tofan $\boldsymbol{e t}$ al. (2002): MRS for lactic acid bacteria incubated at $35^{\circ} \mathrm{C}$ for $72 \mathrm{~h}$ and MMA for yeasts and moulds incubated at $30^{\circ} \mathrm{C}$ for $72 \mathrm{~h}$. The number of colony forming units was obtained by reading at Colony Star (Funke Gerber, Germany) and the data (growth counts) were transformed to $\log _{10}$ values.

\section{pH and Water Activity}

The $\mathrm{pH}$ value was recorded by a $\mathrm{pH}$ meter (HQ11d $\mathrm{pH}$ by $\mathrm{HACH}$ ), the glass electrode being immersed in the homogenate of minced meat at the end of microbiological analysis, according to SR ISO 2917:2007. The water activity $\left(a_{w}\right)$ value was determined by a water activity meter (AquaLab LITE by Decagon, USA).

\section{Physicochemical Analysis}

The water content was determined by using gravimetric method according to SR ISO 1442:2010 and Soxhlet method was applied to establish the total fat content (Soxhlet Extractors - SER 148, VELP SCIENTIFICA, Italy), considering SR ISO 1443:2008. We determined total proteins by using Kjeldahl analysis method (SR ISO 937:2007), with the following steps: digestion (mineralization) of organic substances in acidic medium (Kjeldahl Digestion Units - DK 6 VELP Scientifica, Italy), distillation and capturing nitrogen in a solution of $0.1 \mathrm{~N} \mathrm{H}_{2} \mathrm{SO}_{4}$ (Kjeldahl Distillation Units - UDK 129, VELP Scientifica, Italy), titration of $0.1 \mathrm{~N} \mathrm{H}_{2} \mathrm{SO}_{4}$ excess with $0.05 \mathrm{~N} \mathrm{NaOH}$ solution in the presence of Tashiro indicator. The determination of easily hydrolysable nitrogen (according to $\mathbf{S R}$ 9065-7:2007) was performed based on the following operations: distillation in aqueous solution (in the presence of $\mathrm{MgO}$ and paraffin oil) distillate capture in measured volume of $0.1 \mathrm{~N} \mathrm{H}_{2} \mathrm{SO}_{4}$ solution and final titration of the excess acid with $0.1 \mathrm{~N} \mathrm{NaOH}$ solution.

\section{RESULTS AND DISCUSSION}

\section{The properties of essential oils}

The DPPH method was used to evaluate the antioxidant capacity of basil rosemary and thyme essential oils in comparison with known synthetic antioxidant $\mathrm{L}(+)$-ascorbic acid. The disappearance of the DPPH radical based on the absorbance at $518 \mathrm{~nm}$ wavelength can be monitored by decreasing of optical density. Based on their antioxidant capacity, spice essential oils can be sorted in descending order: thyme (Thymus vulgaris L.) > oregano (Origanum vulgare L.) $>$ rosemary (Rosmarinus officinalis L.). The DPPH radical scavenging activities of all the essential oils (oregano, rosemary and thyme) increased with the increasing of concentration.

Antioxidant capacities in concentrations series of oregano, rosemary and thyme essential oil and ascorbic acid were used to calculate the effective relative concentration $\mathrm{EC}_{50}$. The concentration of essential oils that caused $50 \%$ neutralization of DPPH radicals ( $\mathrm{EC}_{50}$ values), were calculated from the plot of inhibition percentage against concentration. A higher DPPH radical scavenging activity was associated with a lower $\mathrm{EC}_{50}$ value. $\mathrm{EC}_{50}$ values of scavenging $\mathrm{DPPH}$ radicals for rosemary, oregano and thyme essential oils were, $9.423 \pm 0.06$ $\mu \mathrm{g} / \mathrm{mL}, 7.258 \pm 0.02 \mu \mathrm{g} / \mathrm{mL}$ and $3.067 \pm 0.09 \mu \mathrm{g} / \mathrm{mL}$, respectively, while ascorbic acid registered an $\mathrm{EC}_{50}$ of $161.578 \pm 0.03 \mu \mathrm{g} / \mathrm{mL}$.

The results are consistent with previous reported data on antioxidant activity of essential oils of oregano (Lagouri et al. 1993; Özcan 1999; Proestos et al. 2013b), rosemary (Hussain et al. 2010; Kadri et al. 2011) and thyme (Kähkönen et al. 1999; Juki and Milo 2005) respectively. $\mathrm{EC}_{50}$ values generally vary considerably among studies, fact that can be explained by different chemical compositions of essential oils of oregano, rosemary and thyme, due to different environmental and genetic factors, different chemotypes and the nutritional status of the plants.

Thyme essential oil analyses by gas chromatography coupled with mass spectrometry (GC-MS) have revealed a significant quantitative differences between the oils (due to genotopic and environmental differences, namely, climate, location, temperature, fertility, diseases and pest exposure) within species (Wojdylo et al. 2007) for seven compounds: the alcohols $\alpha$-terpineol and linalool, the two isomeric phenols carvacrol and thymol, their precursor $\alpha$ terpinene, $p$-cymene and $\alpha$-pinene. The concentration of these components varied greatly among the oils examined, in particularly that of carvacrol (from 2.8 to $20.6 \%$ ), $p$-cymene (from 4.1 to $27.6 \%$ ) and $\alpha$-pinene (from 0.8 to $25.2 \%$ ). Cosentino and others (1999) observed that the sum of the two phenols and their precursors constituted the bulk of each essential oil are: $53.6 \%, 74.9 \%, 86.9 \%$ and $77.3 \%$ of the total oil, respectively. Strong antioxidant activity is attributed to carvacrol and thymol (Sacchetti et al. 2005). Oregano oil has a high content of phenolic monoterpenes $(35.0 \%$ thymol and carvacrol $32.0 \%$ ) and monoterpenic hydrocarbons (10.5\% $\gamma$-terpinene, $9.1 \%$-cymene, $3.6 \% \alpha$-terpinene) with a strong antioxidant (Kulisic et al. 2004; Rocha-Guzmán et al. 2007) and antimicrobial character (Burt 2004), more than 48 compounds being chromatographically identified (Liolios et al. 2009). Rosemary contains a number of phytochemicals, including rosmarinic acid, camphor, caffeic acid, ursolic acid and betulinic acid (Keokamnerd et al. 2008), the high levels of phenolic compounds leading to its great antioxidant activity. The antioxidan activity of rosemary extract and its constituents, carnosic acid, carnosol and rosmarinic acid is stronger than $\alpha$-tocopherol, butylated hydroxyltoluene (BHT) or butylated hydroxylanisole (BHA) (Özcan 1999; Almeida-Doria and Regitano- D'arce 2000).

Total phenol content was calculated from the standard curve of gallic acid $\left(y=0.27 x-0.022, r^{2}=0.9929\right)$ and expressed as $\mu \mathrm{g} / \mathrm{mL}$ samples and its values are: $33.12 \mu \mathrm{g} / \mathrm{mL}$ for rosemary oil, $27.58 \mu \mathrm{g} / \mathrm{mL}$ for thyme oil and $23.78 \mu \mathrm{g} / \mathrm{mL}$ for oregano oil.

\section{The essential oils influence on microbiological stability}

Plant extracts, essential oils and edible film coating treatments are proven to extend the shelf life of seafood by the use of natural sources. The potential effects of these treatments are delayed lipid oxidation, inhibited microbial growth and enhanced sensorial properties. Due to their antimicrobial and antioxidant properties, plant extracts and essential oils are promising their use instead of synthetic chemicals (Aymerich et al. 2008; Karre et al. 2013; Erkan et al. 2015). Contaminating bacteria are those specific to meat microbiota, such as Gram positive bacteria (Micrococcus, Corynebacterium) and Gram negative (Acinetobacter, Flavobacterium) bacteria prevail (Banu et al. 2006).

Lactic bacteria are the most resistant Gram-positive bacteria, they can be prevalent in the whole microbiota, without being affected by storage conditions (microaerophilic conditions). They are resistant to salt (4-7\%) and sodium nitrite, being capable of growing at low temperatures in vacuum sealed packaging. Although lactic acid bacteria of Lactobacillus, Streptococcus and Leuconostoc species, are competitive with other spoilage bacteria which they inhibit by antagonism, still their presence is undesirable because they cause meat colour change (turning green) and their presence in high concentrations indicates failure to comply with hygiene conditions, before and after processing (Banu et al. 2006).

Gram positive bacteria are more sensitive to antimicrobial compounds from essential oils than Gram-negative bacteria. Fungi appear to be more sensitive than Gram negative bacteria, although there are very sensitive Gram-negative bacteria (Aymerich et al. 2008; Nicolau 2006).

The contribution of lactic acid bacteria to final flora dependents on types and levels of essential oil (Figure 1). It is necessary to mention that the rate of growth and final counts were affected by the addition of essential oil (Figures 1 and 2). The control samples showed the highest total viable counts of lactic acid bacteria and yeast and mould counts respectively, as compared to others containing rosemary, oregano and thyme essential oils with different concentrations. The relatively high initial counts of control samples may be attributed to the grinding process that introduced the microorganisms inside the meat and leads to the increase of total viable counts of meat. Lactic acid bacteria, yeasts and mould counts were gradually increased during cold storage in all samples with different ratios depending on the concentration of oil. Similar studies on the antimicrobial activity of essential oils were performed by Salem et al. (2010) and Erkan and Bilen (2010).

Hać-Szymańczuk et al. (2011), have suggested that rosemary preparations did not exhibit either antibacterial properties against aerobic mesophilic or psychrophilic bacteria. The essential rosemary oil was observed to inhibit the growth of coliform bacteria and enterococci, whereas the dried spice examined was found to increase the counts of aerobic mesophilic bacteria, coliforms and enterococci. 

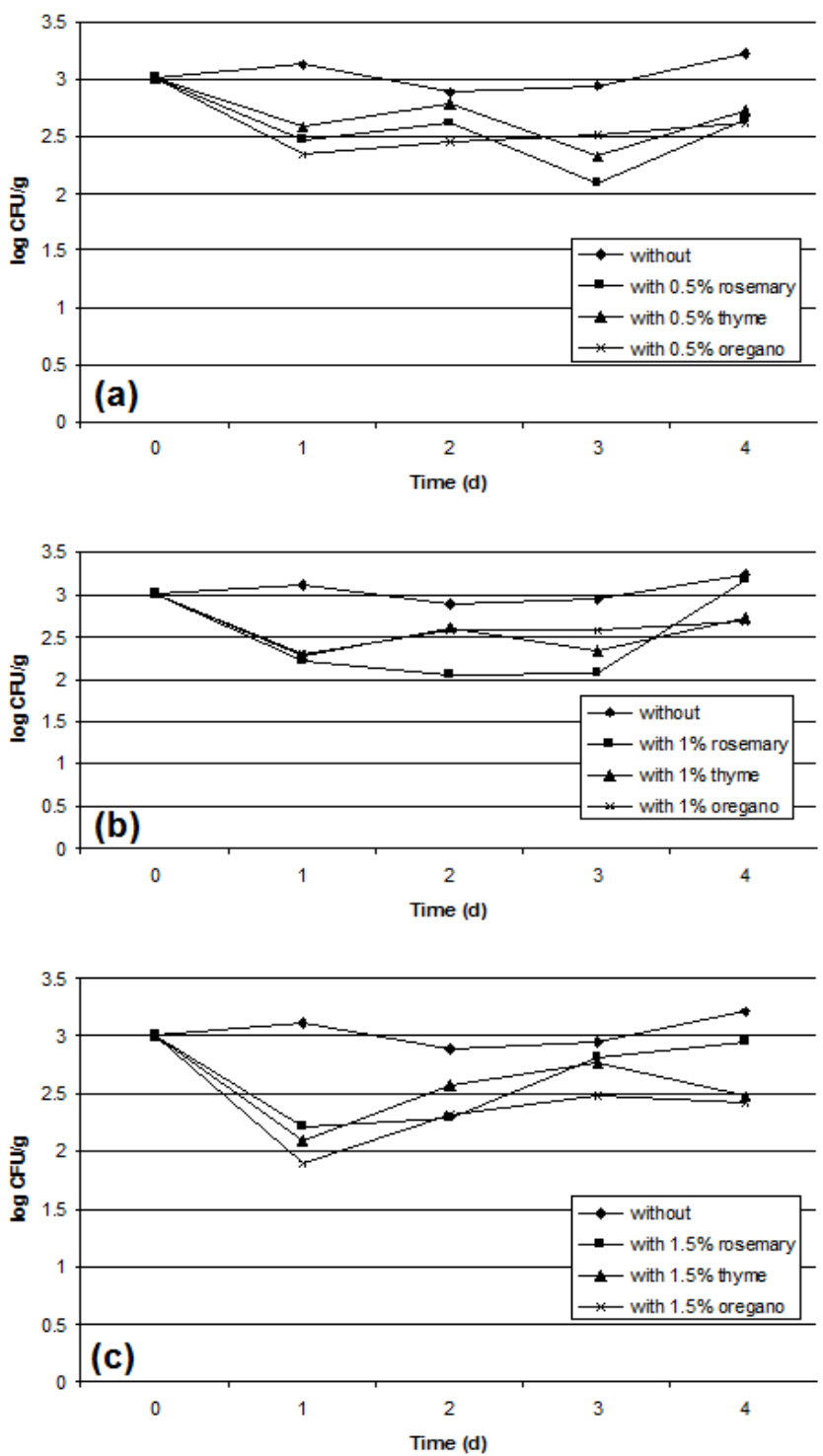

Figure 1 Changes on total viable count of lactic acid bacteria in minced meat without or with rosemary, thyme and oregano essential oils addition (concentration of: (a) $0.5 \%$, (b) $1 \%$ and (c) $1.5 \%$ )
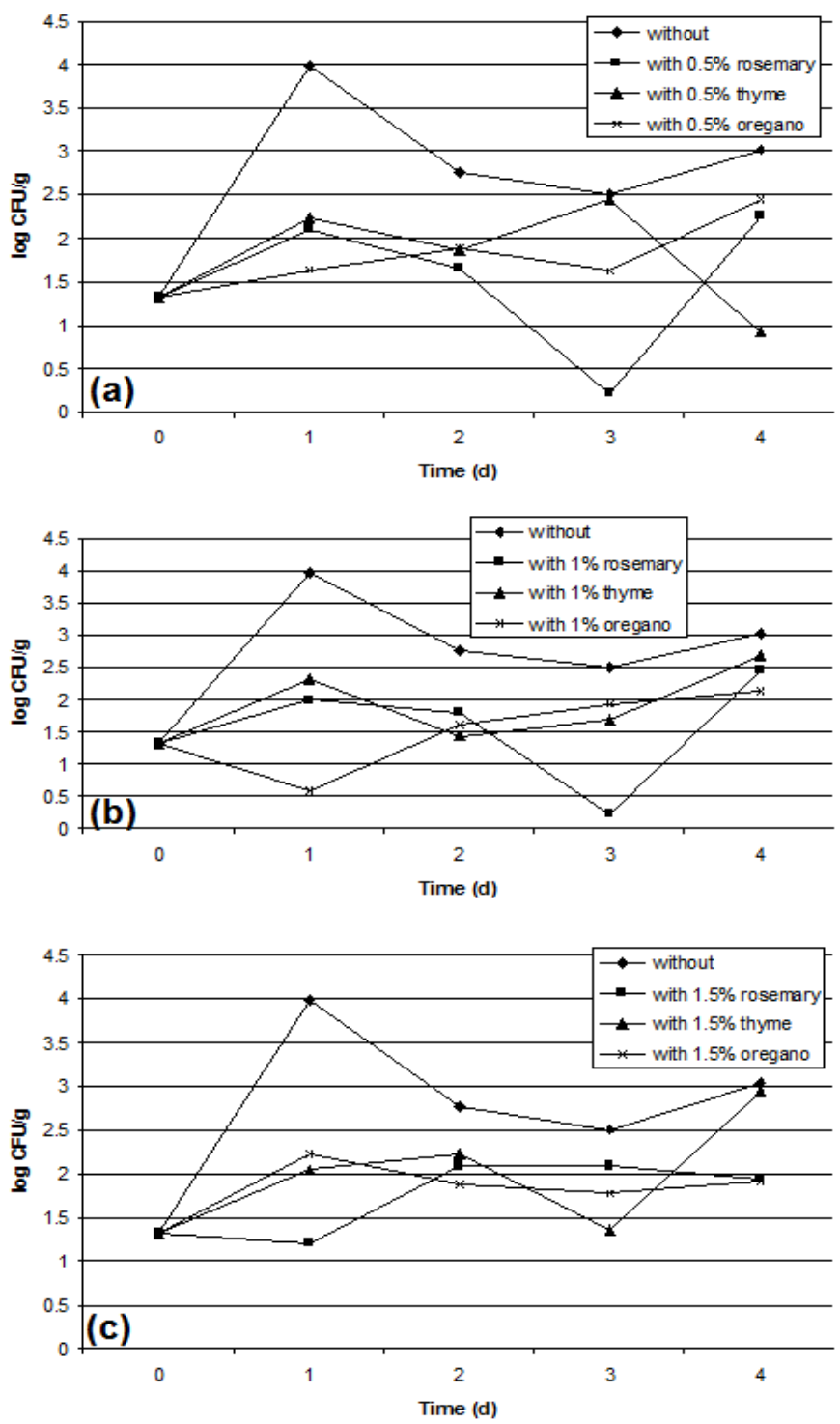

Figure 2 - Changes of yeast and mold counts in minced meat without or with rosemary, thyme and oregano essential oils addition (concentration of: (a) $0.5 \%$, (b) $1 \%$ and (c) $1.5 \%$ )

\section{Water Activity}

The water activity value of minced meat ranged between $0.83-0.92$, during storage for 5 days at $4^{\circ} \mathrm{C}$, Figure 3. The addition of essential oils increased the water activity of minced meat because the water vapour transfer generally occurs through the hydrophilic portion of the film; thus, water vapour permeability depends on the hydrophilic-hydrophobic ratio of the film components from the surface of meat. Water vapour permeability increases with polarity, unsaturation and branching degree of the lipids, depending also on water absorption properties of the polar part of the film and due to the formation of chemical compounds of degradation by lipid oxidation and protein hydrolysis during storage.

Phenolic compounds containing alcohol groups in there chemical structure seems to be a good barrier as compared to aldehyde compounds (e.g., cinnamaldehyde, citral) as hydroxyl group has less affinity for water than for carbonyl groups. All the values obtained for minced meat with rosemary, thyme and oregano essential oil additions (concentration of: $0.5 \%, 1 \%$ and $1.5 \%$ ) stored at $4^{\circ} \mathrm{C}$ for 4 days were between 0.88 and 0.97 (Kingchaiyaphum and Rachtanapun 2012; El Adab et al. 2015). 

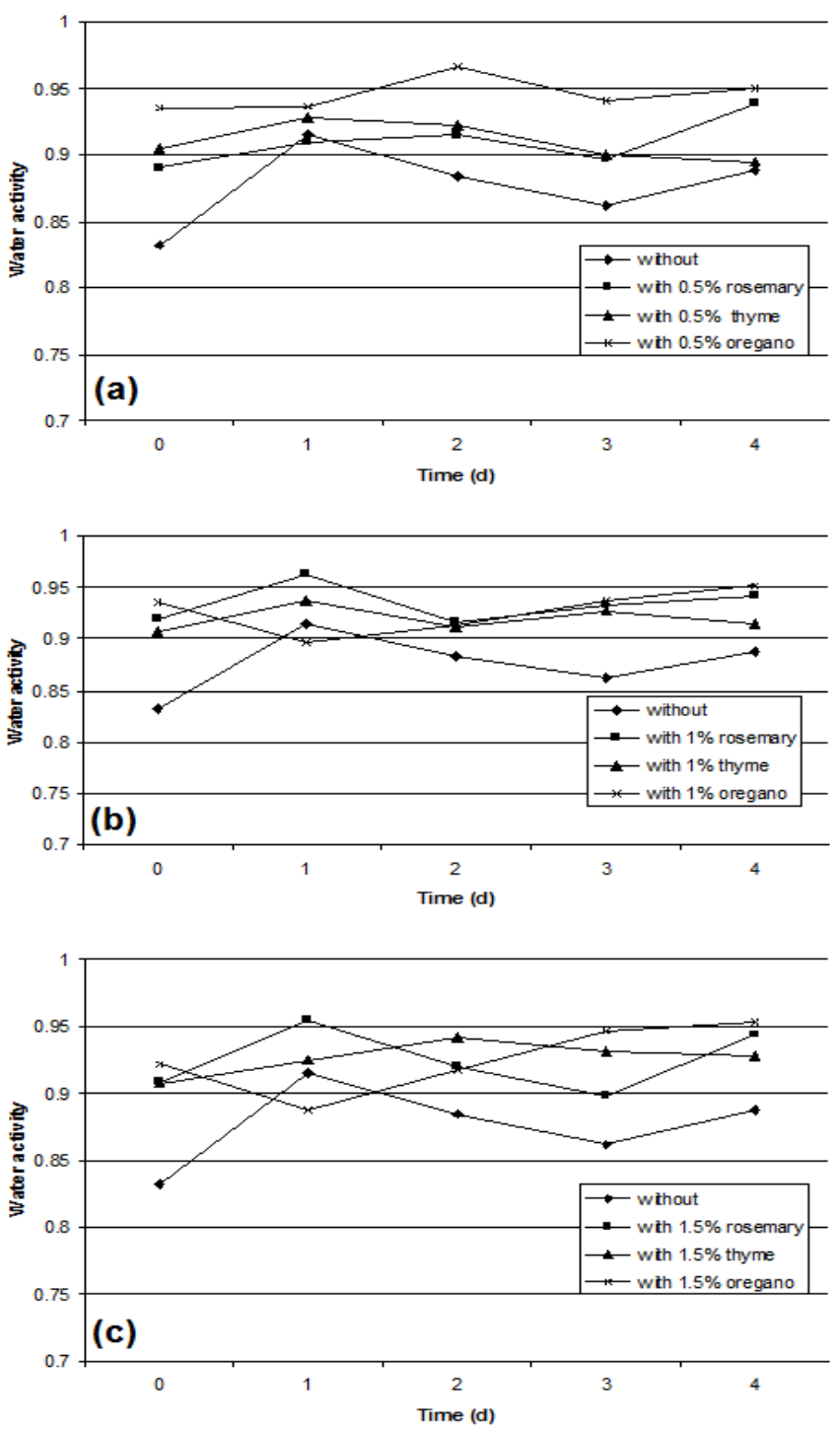

Figure 3 Water activity $\left(a_{w}\right)$ in minced meat without or with rosemary, thyme and oregano essential oils (concentration of: (a) $0.5 \%$, (b) $1 \%$ and (c) $1.5 \%$ ) stored at $4^{\circ} \mathrm{C}$ for 4 days

\section{pH and physicochemical properties of minced meat}

Figure 4 illustrate the maximum range in which the values for the five groups of parameters studied differ in terms of their stability. If the values of moisture, total protein and total fat do not vary significantly in the case of easily hydrolysable nitrogen and $\mathrm{pH}$, an increase in the minimum, maximum and average values can be notice.

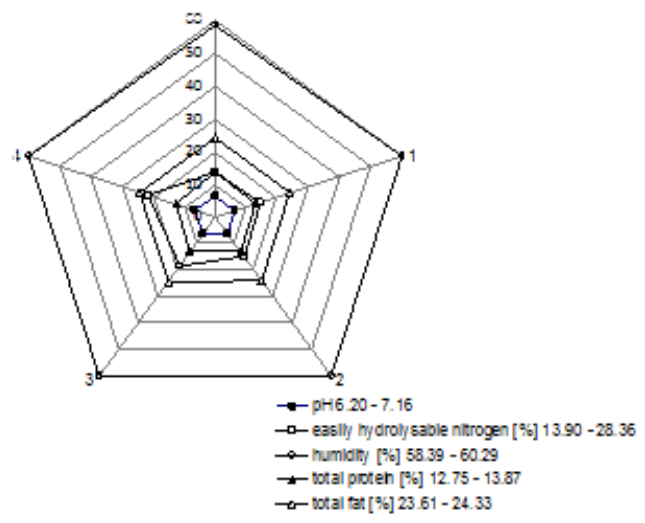

Figure 4 Graphical representation of descriptive statistics for the values of the following parameters: $\mathrm{pH}$, easily hydrolysable nitrogen, humidity, total protein, total fat, on days $0-4$, regardless of the essential oil used

This observation was supported by the data resulted from statistical processing: standard deviation values for moisture, total protein and total fat do not exhibit clear upward trend, while the standard deviation for the easily hydrolysable nitrogen shows a clear upward trend of about 8 times between day 1 and day 4 , and about 7 times for the $\mathrm{pH}$ between the same days as in Table 1 .

Table 1 Variation of standard deviation values for the following parameters: $\mathrm{pH}$, easily hydrolysable nitrogen, humidity, total protein, total fat, on days $0-4$, regardless of the essential oil used

\begin{tabular}{cccccc}
\hline & \multicolumn{5}{c}{ Parameters Analysis } \\
\cline { 2 - 6 } Day & $\mathrm{pH}$ & $\begin{array}{c}\text { Easily } \\
\text { hydrolysable } \\
\text { nitrogen }\end{array}$ & Humidity & $\begin{array}{c}\text { Total } \\
\text { protein }\end{array}$ & Total fat \\
\hline 0 & 0.00 & 0.00 & 0.00 & 0.00 & 0.00 \\
1 & 0.03 & 0.43 & 0.30 & 0.08 & 0.31 \\
2 & 0.03 & 0.93 & 0.31 & 0.02 & 0.14 \\
3 & 0.14 & 2.62 & 0.24 & 0.06 & 0.12 \\
4 & 0.20 & 3.26 & 0.10 & 0.06 & 0.10 \\
\hline
\end{tabular}

This fact suggests that there are differences in growth between the analysed samples. It is considered that some independent factors are causing these differences to a greater or lesser extent. In our case the growth it influenced by the amount and type of oil used. Similar results have been reported by Erkan and Bilen (2010) for bay leaf, thyme, rosemary, black seed, sage, grape seed, flaxseed and lemon essential oil on chub mackerel.

Figures 5 and 6 shows a similar situation both in the evolution of easily hydrolysable nitrogen parameter and in that of $\mathrm{pH}$ parameter. Thus, for both, the factor time (days) was the strongest determinant of the parameters evolution and significant differences between measurements every day were recorded. The analysis of individual differences between days regarding the percentage of easily hydrolysable nitrogen by slope of growth revealed that there are significant differences between days 2 - 3, and $3-4$, suggesting an acceleration from day 2 in increasing the amount of easily hydrolysable nitrogen in the sample. The average difference between the percentages of easily hydrolysable nitrogen was $3.24 \%$ on days 2 and 3 and $2.70 \%$ between days $3-4$. For pH, significant difference between two consecutive days were registered only on days $3-4$, with a mean difference of $0.30 \mathrm{pH}$ value units. Both in the case of easily hydrolysable nitrogen and in that of $\mathrm{pH}$, the amount of oil used was significant to determine differences in the evolution of parameters.

The type of oil used did not influence significantly the evolution in time of easily hydrolysable nitrogen and $\mathrm{pH}$ indicators.

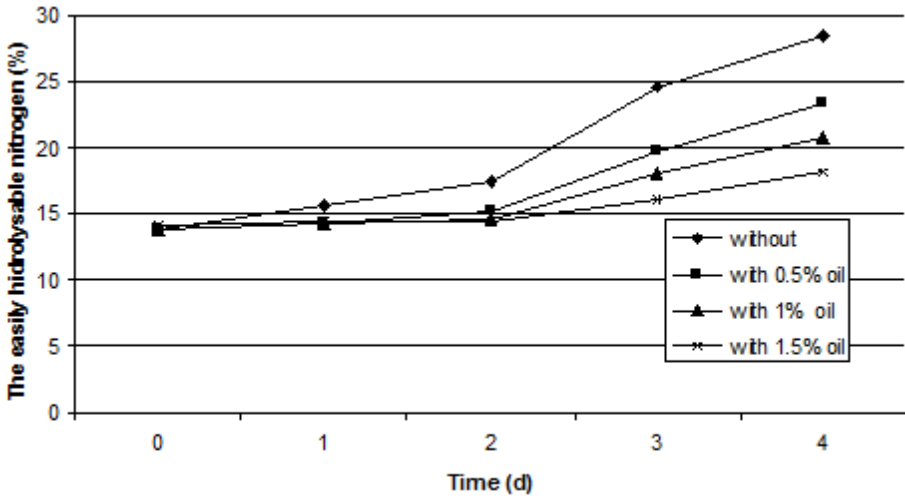

Figure 5 Variation of easily hydrolysable nitrogen percentage on days 0-4, for $0.5 \%, 1.0 \%$ and $1.5 \%$ concentration of oil added

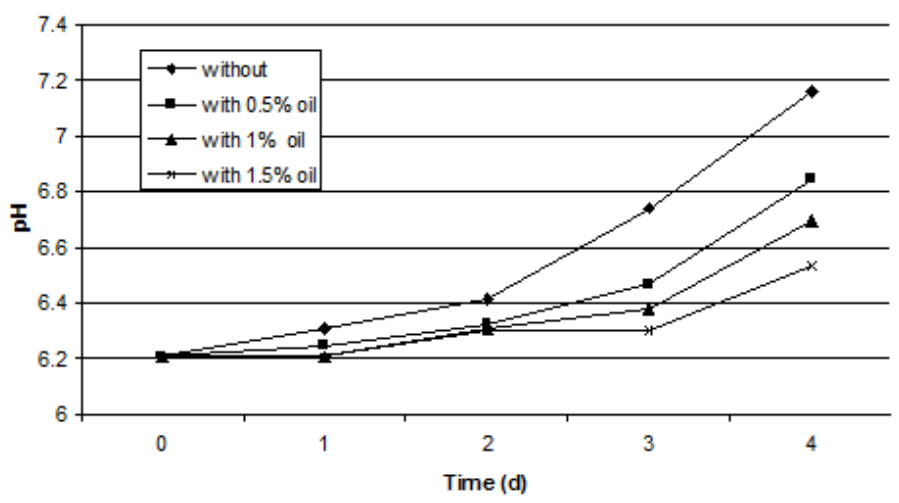

Figure $6 \mathrm{pH}$ variation, on days $0-4,0.5 \%, 1.0 \%$ and $1.5 \%$ concentrations of oil 
Figure 7 illustrate the evolution of easily hydrolysable nitrogen percentage on $0-4$ days, for the control sample and for each type of oil and the amount of oil incorporated. The lines representing the highest oil concentration used are located at the bottom of the graph, and thyme oil of $1.5 \%$ concentration corresponds to the lowest percentage of final easily hydrolysable nitrogen, the slope that increases the percentage of easily hydrolysable nitrogen in days 2-4 being the lowest. Figure 7 confirms the statistical results presented in Table 1, according to which the growth rate of easily hydrolysable nitrogen in all samples is accelerating from day 2 , except for that of thyme oil in concentration of $1.5 \%$ which seems to adjourn the process to the 3 rd day.

The $\mathrm{pH}$ evolution from Figure 8 confirms the results mentioned above, higher concentrations of the oil resulting in a less steep increase slope of $\mathrm{pH}$ value. Also, it can be seen that all three oils at maximum concentration of $1.5 \%$ incorporated adjourn the acceleration from day 2 to 3 rd day that it was found to control sample. The differences between day 2 and day 4 remain considerable. Recent studies demonstrated that evaluation of essential oils in different products with refrigeration and frozen methods (Erkan 2012; Erkan et al. 2011a) or with modified atmosphere packaging (Erkan $\boldsymbol{e t}$ al. 2011b) can be applied as effective conservation methods in order to extend the shelf-life of processed food without the use of chemical preservatives.
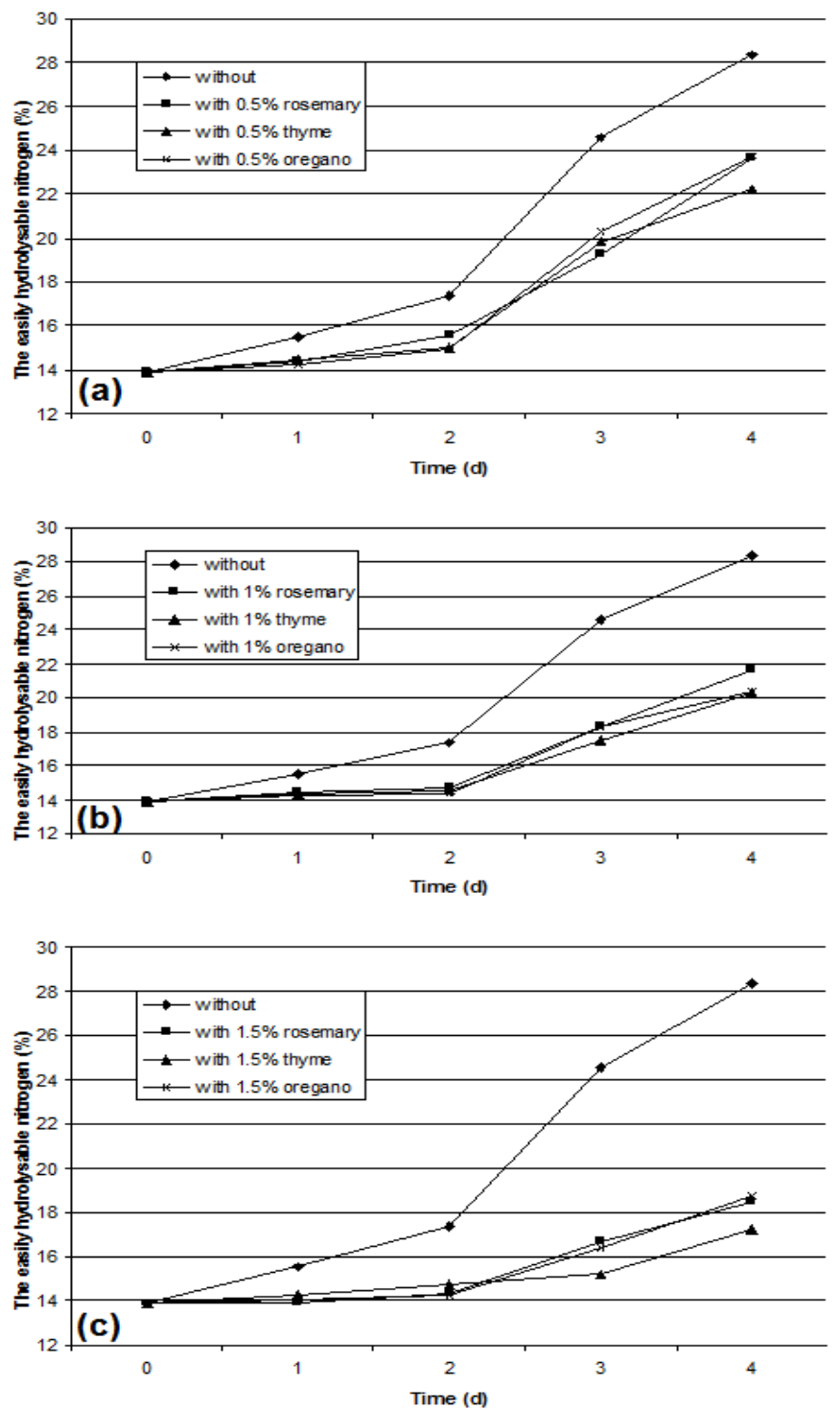

Figure 7 The evolution of the easily hydrolysable nitrogen percentage on days 0 4 , depending on the type and amount of oil used (concentration of: (a) $0.5 \%$, (b) $1 \%$ and (c) $1.5 \%)$
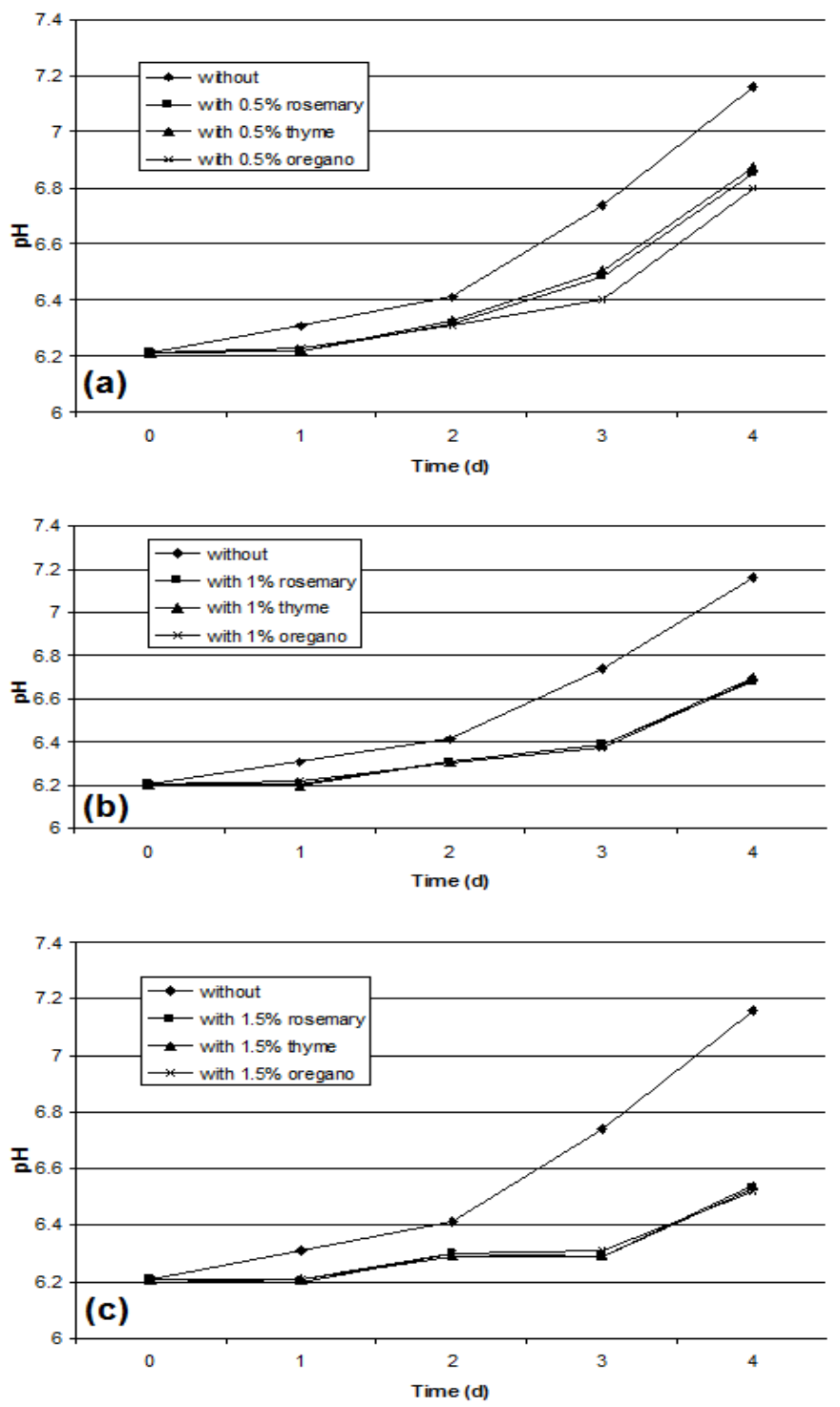

Figure 8 - Evolution of $\mathrm{pH}$ on days 0-4 depending on the type and amount of oil used (concentration of: (a) $0.5 \%$, (b) $1 \%$ and (c) $1.5 \%$ )

\section{CONCLUSION}

In this paper was analysed the influence of three different oils rosemary, thyme and oregano on the physicochemical and microbiological properties of minced meat. The oils analysis were performed by applying DPPH method, also the microbiological activity was evaluated. From the analysis of experimental data and their statistical processing it can be concluded that the incorporation of essential oils in minced meat has differentiated effects depending on the parameter analysed. Sensory properties, with major impact on the purchasing decision, were maintained in the range of acceptability for the samples containing essential oils. Unlike these, the control sample at the end of the test, showed changes in odour and colour being unfit for consumption. Parameters such as humidity, total protein, total fat, are not affected by the type or content of essential oil. Indicators regarding the degree of meat degradation, easily hydrolysable nitrogen and $\mathrm{pH}$ showed increased values from day to day, but lower ones for the samples added with essential oils and much higher for the control sample. When increasing the concentration of essential oil added, the increase is balanced. No significant differences were found in the efficiency between the types of essential oil used.

It should be noted that for the previously named parameters, the rate of increase is not uniform throughout the testing period, an increasing in easily hydrolysable nitrogen accumulation and sample alkalization after the third day were observed. In conclusion, the use of essential oils could improve both microbial stability and sensory quality. Thus, this study suggests the possibility of using thymus, oregano and rosemary oils as natural antioxidant in food industry, where they may be considered natural preservatives to replace synthetic preservatives of which consumers are increasingly distrustful. The pleasant taste, smell and low toxicity indicate their use as additives to prevent bacterial contamination. 


\section{REFERENCES}

Almeida-Doria, R. F., \& Regitano- D'arce, M. A. B. (2000). Antioxidant activity of rosemary and oregano ethanol extracts in soybean oil under thermal oxidation. Ciênc Tecnol Aliment, 20(2), 197-203. http://dx.doi.org/10.1590/S0101 20612000000200013.

Aymerich, T., Picouet, P. A., \& Monfort, J. M. (2008). Decontamination technologies for meat products. Meat Sci., 78, 114-129. http://doi:10.1016/j.meatsci.2007.07.007.

Bakkali, F., Averbeck, S., Averbeck, D., \& Idaomar, M. (2008). Biological effects of essential oils - A review. Food Chem Toxicol., 46, 446 - 475 http://doi:10.1016/j.fct.2007.09.106.

Banu, C., Ionescu, A., Bahrim, G., Dorin, S. S., \& Vizireanu, C. (2006). Biochemistry, microbiology and parasitology meat. AGIR Publishing. Bucharest, (in romanian).

Barnes, J., Anderson, L. A., Gibbons, S., \& Phillipson, J. D. (2005). Echinacea species (Echinacea angustifolia (DC.) Hell., Echinacea pallida (Nutt.) Nutt., Echinacea purpurea (L.) Moench): a review of their chemistry, pharmacology and clinical properties. J Pharm Pharmacol., 57, 929-954. http://doi:10.1211/0022357056127.

Bassolé, I. H. N., \& Juliani, H. R. (2012). Essential Oils in Combination and Their Antimicrobial Properties. Molecules, 17, 3989-4006. http://doi:10.3390/molecules17043989.

Brand-Williams, W., Cuvelier, M. E., \& Berset, C. (1995). Use of free radica method to evaluate antioxidant activity. Lebensm-WissTechnol., 28, 25-30. http://doi:10.1016/S0023-6438(95)80008-5.

Burt, S. (2004). Essential oils: Their antibacterial properties and potentia applications in foods - A review. Int J Food Microbiol., 94, 223-253. http://doi:10.1016/j.ijfoodmicro.2004.03.022.

Chao, L. K., Hua, K. F., Hsu, H. Y., Cheng, S. S., Lin, I. F., Chen, C. J., Chen, S. T., \& Chang, S. T. (2008). Cinnamaldehyde inhibits pro-inflammatory cytokines secretion from monocytes/macrophages through suppression of intracellula signaling. Food Chem Toxicol., 46, 220-231. http://doi:10.1016/j.fct.2007.07.016.

Chatli, M. K., \& Joseph, S. (2014). Augmentation of shelf life of meat with natural antioxidants: an overview. J. Meat Sci Technol., 2, 16-30 http://www.jakraya.com/journal/jmst.

Cosentino, S., Tuberoso, C. I. G., Pisano, B., Satta, M., Mascia, V., Arzedi, E., \& Palmas, F. (1999). In-vitro antimicrobial activity and chemical composition of Sardinian Thymus essential oils. Lett Appl Microbiol., 29, 130-135. http://doi:10.1046/j.1472-765X.1999.00605.x.

Cox, S. D., \& Markham, J. L. (2007). Susceptibility and intrinsic tolerance of Pseudomonas aeruginosa to selected plant volatile compounds. J Appl Microbiol., 103, 930-936. http://doi:10.1111/j.1365-2672.2007.03353.x.

Dung, N. T., Bajpai, V. K., Yoon, J. I., \& Kang, S. C. (2009). Anti-inflammatory effects of essential oil isolated from the buds of Cleistocalyx operculatus (Roxb.) Merr and Perry. Food Chem Toxicol., 47, 449-453. http://doi:10.1016/j.fct.2008.11.033.

El Adab, S., Essid, I., \& Hassouna, M. (2015). Microbiological, biochemical and textural characteristics of a Tunisian dry fermented poultry meat sausage inoculated with selected starter cultures. J Food Safety, 35, 75-85 http://doi:10.1111/jfs.12164

Erkan, N., Doğruyol, H., Günlü, A., \& Genç, İ. Y. (2015). Use of natura preservatives in seafood: plant extracts, edible film and coating, review article. $J$ Food Health Sci., 1, 33-49. http://doi:10.3153/JFHS15004.

Erkan, N. (2012). The effect of thyme and garlic oil on the preservation of vacuum packaged hot smoked rainbow trout (Oncorhynchus mykiss). Food Bioprocess Technol., 5 (4): 1246-1254. http://doi:10.1007/s11947-010-0412-7.

Erkan, N., Tosun, Ş.Y., Ulusoy, Ş., \& Üretener, G. (2011a). The use of a thyme and laurel essential oil treatments to extend the shelf life of bluefish (Pomatomus saltatrix) during storage in ice. $J$ für Verb Lebens., 6, 39-48. http://doi:10.1007/s00003-010-0587-x.

Erkan, N., Ulusoy, S., \& Tosun, Y. (2011b). Effect of combined application of plant extract and vacuum packaged treatment on the quality of hot smoked rainbow trout. $J$ für Verb Lebens., 6, 419-426. http://doi:10.1007/s00003-0110665-8.

Erkan, N., \& Bilen, G. 2010. Effect of essential oils treatment on the frozen storage stability of chub mackerel fillets. J für Verb Lebens., 5, 101-110. http://doi:10.1007/s00003-009-0546-6.

Faleiro, M. L. (2011). The mode of antibacterial action of essential oils. In: Science against microbial pathogens: communicating current research and technological advances. Microbiology book series-2011, Edition. A. MendezVilas (Editor). 2, 1143-1156.

Faleiro, M. L., Miguel, M. G., Ladeiro, F., Venâncio, F., Tavares, R., Brito, J. C., Figueiredo, A. C., Barroso, J. G., \& Pedro, L. G. (2003). Antimicrobial activity of essential oils isolated from Portuguese endemic species of Thymus. Lett Appl Microbiol., 36, 35-40. http://doi:10.1046/j.1472-765X.2003.01259.x.

Fasseas, M. K., Mountzouris, K. C., Tarantilis, P. A., Polissiou, M., \& Zervas, G. (2008). Antioxidant activity in meat treated with oregano and sage essential oils. Food Chem., 106, 1188-1194. http://doi:10.1016/i.foodchem.2007.07.060.
Frankel, E. N., \& Meyer, A.S. (2000). The problems of using onedimensional methods to evaluate multifunctional foods and biological antioxidants. J Sci Food Agric., 80, 1925-1941. http://doi:10.1002/1097-0010(200010)80:13<1925::AIDJSFA714>3.0.CO;2-4.

Fujita, N., Saito, Y., Nitto, Y., Ito, T., Mizuguchi, H., Endo, M., \& Ogata, T. (2012). Folin - Chiocaleau colorimetric analysis using a scanner for rapid determination of total polyphenol content in many test samples. Studies in

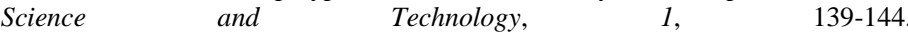
https://www.jstage.jst.go.jp/article/sst/1/2/1 139/article/-char/ja/.

Hać-Szymańczuk, E., Lipińska, E., \& Stasiuk, M. (2011). The effect of rosemary preparations on the microbial quality and TBARS value of model pork batters Acta Sci Pol Technol Aliment, 10, 165-174. http://www.food.actapol.net/issue2/volume/3_2_2011.pdf.

Helander, I. M., Alakomi, H.L., Latva-Kala, K., Mattila-Sandholm, T., Pol, I., Smid, E. J., Gorris, L. G. M., \& von Wright, A. (1998). Characterization of the Action of Selected Essential Oil Components on Gram-Negative Bacteria. J Agric Food Chem., 46, 3590-3595. http://doi:10.1021/jf980154m.

Hussain, A. I., Anwar, F., Chatha, S. A. S., Jabbar, A., Mahboob, S., \& Nigam, P. S. (2010). Rosmarinus officinalis essential oil: antiproliferative, antioxidant and antibacterial activities. Brazilian $J$ Microbiol., 41, 1070-1078. http://doi:10.1590/S1517-838220100004000027.

Juki, M., \& Milo, M. (2005). Catalytic Oxidation and Antioxidant Properties of Thyme Essential Oils (Thymus vulgarae L.). Croat Chem Acta, 78, 105-110. http://hrcak.srce.hr/index.php?show=clanak\&id clanak jezik=4667\&lang=en.

Kadri, A., Zarai, Z., Ben, C., Bekir, A., Gharsallah, N., Damak, M., \& Gdoura, R. (2011). Chemical constituents and antioxidant properties of Rosmarinus officinalis L. essential oil cultivated from South-Western Tunisia. J Med Plants Res., 5, 6502-6508. http://doi:10.5897/JMPR11.423.

Kähkönen, M. P., Hopia, A.I., Vuorela, H. J., Rauha, J. P., Pihlaja, K., Kujala, T. S., \& Heinonen, M. (1999). Antioxidant Activity of Plant Extracts Containing Phenolic Compounds. J Agric Food Chem., 47, 3954-3962. http://doi:10.1021/jf9901461.

Karre, L., Lopez, K., \& Getty, K. J. K. (2013). Natural antioxidants in meat and poultry products, Review. Meat Sci., 94, 220-227. http://doi:10.1016/j.meatsci.2013.01.007.

Keokamnerd, T., Acton, J. C., Han, I. Y., \& Dawson, P. L. (2008). Effect of Commercial Rosemary Oleoresin Preparations on Ground Chicken Thigh Meat Quality Packaged in a High-Oxygen Atmosphere. Poult Sci., 87, 170-179. http://doi:10.3382/ps.2007-00066.

Kingchaiyaphum, W., \& Rachtanapun, C. (2012). Antimicrobial and antioxidative activities of essential oils in Chinese sausage (Kun-Chiang). As $J$ Food Ag-Ind., 5, 156-162. www.ajofai.info.

Kulisic, T., Radonic, A., Katalinic, V., \& Milos, M. (2004). Use of different methods for testing antioxidative activity of oregano essential oil. Food Chem. 85, 633-640. http://doi:10.1016/i.foodchem.2003.07.024.

Lagouri, V., Blekas, G., Tsimidou, M., Kokkini, S., \& Boskou, D. (1993) Composition and antioxidant activity of essential oils from Oregano plants grown wild in Greece. Z Lebensm Unters Forsch., 197, 20-23. http://doi:10.1007/BF01202694.

Liolios, C. C., Gortzi, O., Lalas, S., Tsaknis, J., \& Chinou, I. (2009). Liposomal incorporation of carvacrol and thymol isolated from the essential oil of Origanum dictamnus L. and in vitro antimicrobial activity. Food Chem., 112, 77-83. http://doi:10.1016/j.foodchem.2008.05.060.

Nicolau, A. (2006). General Microbiology, Factors influencing the growth of microorganisms, Academic Publishing, Bucharest, (in romanian).

Ocaña-Fuentes, A. (2012). Supercritical Fluid Extraction of Oregano (Origanum vulgare) Essentials Oils Show some In Vitro Anti-Inflammatory Effects Based on Modifying Adipokine Secretion and Gene Expression on TNF- $\alpha$-Induced Adipocytes, Inflammatory Diseases - Immunopathology, Clinical and Pharmacological Bases, Edited by Dr Mahin Khatami, ISBN 978-953-307-9110

Özcan, M. (1999). Antioxidant activity of rosemary (Rosmarinus officinalis L.) extracts on natural olive and sesame oils. Grasas y Aceites, 50, 355-358. http://doi:10.3989/gya.1999.v50.i5.679.

Ozkan, A., \& Erdoğan, A. (2011). A comparative evaluation of antioxidant and anticancer activity of essential oil from Origanum onites (Lamiaceae) and its two major phenolic components. Turk J Biol., 35, 735-742. http://doi:10.3906/biy1011-170.

Proestos, C., Zoumpoulakis, P., \& Sinanoglou, V. J. (2013a). Determination of Plant Bioactive Compounds. Antioxidant Capacity and Antimicrobial Screening. Focusing on Modern Food Industry (FMFI), 2, 26-35. www.fmfi-journal.org. Proestos, C., Lytoudi, K., Mavromelanidou, O. K., Zoumpoulakis, P., \& Sinanoglou, V. J. (2013b). Antioxidant Capacity of Selected Plant Extracts and Their Essential Oils. Antioxidants, 2, 11-22. http://doi:10.3390/antiox2010011. Ramchoun, M., Sellam, K., Harnafi, H., Alem, C., Benlyas, M., Khallouki, F., \& Amrani, S. (2015). Investigation of antioxidant and antihemolytic properties of Thymus satureioides collected from Tafilalet Region, south-east of Morocco. Asian Pac J Trop Biomed., 5, 93-100. http://doi:10.1016/S2221-1691(15)30151$\underline{9}$. 
Rocha-Guzmán, N. E., Gallegos-Infante, J. A., González-Laredo, R. F., RamosGómez, M., Rodríguez-Muñoz, M. E., Reynoso-Camacho, R., Rocha-Uribe, A., \& Roque-Rosales, M. R. (2007). Antioxidant effect of oregano (Lippia berlandieri v. Shauer) essential oil and mother liquors. Food Chem., 102, 330 335. http://doi:10.1016/j.foodchem.2006.05.024.

Roldán, L. P., Díaz, G. J., \& Duringer, J. M. (2010). Composition and antibacterial activity of essential oils obtained from plants of the Lamiaceae family against pathogenic and beneficial bacteria. Rev Colomb Cienc Pecu., 23, 451-461. http://rccp.udea.edu.co.

Sá, R. C. S., Andrade, L. N., Oliveira, R. R. B., \& Sousa, D. P. (2014). A Review on Anti-Inflammatory Activity of Phenylpropanoids Found in Essential Oils. Molecules, 19, 1459-1480. http://doi:10.3390/molecules19021459.

Sacchetti, G., Maietti, S., Muzzoli, M., Scaglianti, M., Manfredini, S., Radice, M., \& Bruni, R. (2005). Comparative evaluation of 11 essential oils of different origin as functional antioxidants, antiradicals and antimicrobials in foods. Food Chem., 91, 621 - 632. http://doi:10.1016/j.foodchem.2004.06.031.

Salem, A. M., Amin, R. A., \& Afifi, G. S. A. (2010). Studies on Antimicrobial and Antioxidant Efficiency of Some Essential Oils in Minced Beef. J Am Sci., 6 , 691-700. http://www.americanscience.org.

Sivasothy, Y., Awang, K., Ibrahim, H., Thong, K. L., Fitrah, N., Koh, X. P., \& Tan, L. K. (2012). Chemical composition and antibacterial activities of essential oils from Zingiber spectabile Griff. J Essent Oil Res., 24, 305 - 313 http://dx.doi.org/10.1080/10412905.2012.676803.

Skandamis, P. N., \& Nychas, G. J. E. (2001). Effect of oregano essential oil on microbiological and physico-chemical attributes of minced meat stored in air and modified atmospheres. $J$ Appl Microbiol., 91, 1011-1022. http://doi:10.1046/j.1365-2672.2001.01467.x.

SR. 2007. Meat and meat products. Determination of easily hydrolysable nitrogen content, (in romanian). Domains/67/67.120/67.120.10. SR 90657:2007/C91:2009.

http://magazin.asro.ro/index.php? $1 \mathrm{~g}=2 \& \mathrm{pag}=3 \& \mathrm{cls}=1 \&$ dom $=67 \& \mathrm{gr}=120 \& \mathrm{sgr}=1$ 0\&id $\mathrm{p}=35336866$

SR ISO. 2010. Meat and meat products. Determination of moisture content (Reference method), (in romanian). Domains/67/67.120/67.120.10. SR ISO 1442:2010.

http://magazin.asro.ro/index.php? $1 \mathrm{~g}=2 \& \mathrm{pag}=3 \& \mathrm{cls}=1 \& \mathrm{dom}=67 \& \mathrm{gr}=120 \& \mathrm{sgr}=1$ 0\&id_p $=35337272$

SR ISO. 2008. Meat and meat products. Determination of total fat content, (in romanian). Domains/67/67.120/67.120.10. SR ISO 1443:2008 http://magazin .asro.ro/index.php?lg=2\&pag=3\&cls=1\&dom=67\&gr=120\&sgr=1 0\&id $\mathrm{p}=35332460$

SR ISO. 2007. Meat and meat products. Measurement of $p H$. Reference method, (in romanian). Domains/67/67.120/67.120.10. SR ISO 2917:2007. http://magazin.asro.ro/index.php?pag $=3 \& 1 \mathrm{lg}=1 \& \mathrm{cls}=1 \& \mathrm{dom}=67 \& \mathrm{gr}=120 \& \mathrm{sgr}=1$ 0\&id $\mathrm{p}=35328888$.

SR ISO. 2007. Meat and meat products. Determination of nitrogen content (Reference method), (in romanian). Domains/67/67.120.10. SR ISO 937:2007. http://magazin.asro.ro/index.php?pag $=3 \& 1 \mathrm{~g}=2 \& \mathrm{cls} 0=1 \& \mathrm{cls} 1=0 \& \mathrm{cls} 2=0 \& \mathrm{cls} 3=0$ \&cls4=0\&id_p=35329411

Su, D., Ti, H., Zhang, R., Zhang, M., Wei, Z., Deng, Y., Guo, J. (2014). Structural elucidation and cellular antioxidant activity evaluation of major antioxidant phenolics in lychee pulp. Food Chem., 158, 385-391. http://doi:10.1016/j.foodchem.2014.02.134.

Tofan, C., Bahrim, G., Nicolau, A., \& Zara, M. (2002). Microbiology of food and laboratory techniques, AGIR Publishing House, Bucharest, (in romanian).

Wojdyło, A., Oszmiański, J., \& Czemerys, R. (2007). Antioxidant activity and phenolic compounds in 32 selected herbs. Food Chem., 105, 940-949. http://doi:10.1016/j.foodchem.2007.04.038.

Zhang, W., Xiao, S., Samaraweera, H., Lee, E. J., \& Ahn, D. U. (2010) Improving functional value of meat products - Review. Meat Sci., 86, 15-31. http://doi:10.1016/j.meatsci.2010.04.018.

Zhou, G. H., Xu, X. L., Liu, Y. (2010). Preservation technologies for fresh meat - A review. Meat Sci., 86, 119-128, http://doi:10.1016/j.meatsci.2010.04.033. 